\title{
Between-habitat distributions of pond tadpoles and their insect predators in response to fish presence
}

\author{
Janusz Kloskowski iD - Marek Nieoczym • Robert Stryjecki
}

Received: 3 August 2019/Revised: 11 January 2020/Accepted: 25 January 2020/Published online: 1 February 2020

(C) The Author(s) 2020

\begin{abstract}
Between-habitat distributions of prey shared by multiple predators depend on habitat use by the predators, whose own distributions may interact. We used a large-scale, whole-system natural experiment to examine distributions of anuran tadpoles and insect predators between pond microhabitats with contrasting complexity (open water vs emergent littoral vegetation) in drainable ponds that were either kept fishless or stocked with fish. Total relative densities of insect predators did not significantly differ with respect to the fish status of the ponds. Individual anuran taxa responded variously, but only fish-tolerant Bufo bufo densities were higher in the presence of fish. The densities of both insect predators and tadpoles showed positive interactions between fish presence and the use of complex littoral habitat. The habitat shift to littoral vegetation could be indirectly amplified by fish adverse impact on submerged macrophytes, the main structured microhabitat in open-water areas. Irrespective of mechanisms of fish effects (direct consumption, behavioral deterrence or alteration of
\end{abstract}

Handling editor: Dani Boix

J. Kloskowski ( $\square)$

Institute of Zoology, Poznań University of Life Sciences, Wojska Polskiego 71C, 60-625 Poznań, Poland

e-mail: janusz6kl@gmail.com

M. Nieoczym · R. Stryjecki

Department of Zoology and Animal Ecology, University of Life Sciences, Akademicka 13, 20-950 Lublin, Poland habitat conditions), aggregation of both tadpoles and insect predators in littoral vegetation may put tadpoles at greater risk of predation by insects, a potentially important factor of amphibian mortality in waters containing fish.

Keywords Antipredator response $\cdot$ Habitat complexity · Non-consumptive effects · Predator-prey interactions $\cdot$ Littoral vegetation $\cdot$ Spatial behavior

\section{Introduction}

Distributions of predators and prey across space can have major community-level consequences (Krivan, 1997; Lima, 2002). Predation has been demonstrated to alter habitat use and distribution of prey organisms (e.g., González \& Tessier, 1997; Dupuch et al., 2009; Hanisch et al., 2012). Much attention has been given to the influence of multiple predators on prey populations and the role of interactions among predators in shaping predator-prey relationships (reviewed in Sih et al., 1998) because effects of multiple predators can depart from predictions based on pairwise relationships (e.g., Soluk \& Collins, 1988; Wissinger \& McGrady, 1993; McCoy et al., 2012; Palacios et al., 2018). In aquatic systems, predators that typically forage actively in simple open habitats are hampered by vegetation, and thus complex-structured microhabitats may relax their 
predation pressure on prey populations (Crowder \& Cooper, 1982; Heck \& Crowder, 1991). Multiple predators interact with one another, including intraguild predation (IGP), as well as with habitat complexity (González \& Tessier, 1997; Swisher et al., 1998; Anderson \& Semlitsch, 2016). Prey shared by multiple predators should choose among habitats according to their use by top predators and by mesopredators, whose own spatial distributions are dependent on the distribution of top predators.

Fish are notorious for their strong top-down impacts on freshwater communities; the occurrence of some macroinvertebrates and amphibian larvae is limited to waters where fish are absent (Schilling et al., 2009; de Mendoza et al., 2012; Holbrook \& Dorn, 2016). Predatory effects of fish can be confounded by a plethora of indirect interactions, including alteration of habitat conditions ('ecosystem engineering') in some species (Parkos et al., 2003; Matsuzaki et al., 2007). Predaceous insects, as mesopredators, may respond to predation risk from fish, as well as to cues of prey, while both fish and insects send danger cues to lower trophic levels (Burks \& Lodge, 2002; Inoda, 2012). Prey shared by fish and insect predators may be capable of distinguishing among their cues and correspondingly fine-tune their antipredator behavior (Semlitsch \& Reyer, 1992; Van Buskirk, 2001; Relyea, 2003; Smith \& Awan, 2009). The different modes of prey detection and capture by fish and aquatic insects correspond with their habitat use. Most fish predators are visually oriented (Healey, 1984). Their ability to capture prey decreases in structurally complex habitats formed by macrophytes (e.g., Crowder \& Cooper, 1982; Savino \& Stein, 1982; Diehl \& Kornijów, 1998), although small-bodied fish or fish that ambush rather than chase prey are less affected, or not at all (Diehl \& Kornijów, 1998; Eklöv \& VanKooten, 2001; de Mendoza et al., 2012). Consequently, prey should prefer vegetated or otherwise structured habitats in the presence of fish (Fairchild \& Holomuzki, 2005; Hanisch et al., 2012, but see Gunzburger \& Travis, 2005; Smith et al., 2009). Although predatory insects use visual cues as well, many taxa rely greatly on tactile or chemical information to detect prey (e.g., Richards \& Bull, 1990; Inoda, 2012). Predatory insects use aquatic vegetation as a perch site, where they ambush their prey; moreover, as they are typically smaller than fish predators, they may display better maneuvering ability in structurally complex habitats (Heck \& Crowder, 1991; Fairchild \& Holomuzki, 2005). Many insect predators have been reported to easily alternate their habitat and foraging strategies; in structured habitats insects can shift between active foraging and a sit-andwait mode, depending on the density, activity and evasiveness of prey and on interference from other predators (Akre \& Johnson, 1979; Formanowicz, 1982; Johansson, 1991; Michel \& Adams, 2009). Consequently, insect predators display higher abundance and diversity in structurally complex, vegetated habitats than in open water (Semlitsch \& Reyer, 1992; Babbitt \& Tarr, 2002; Rennie \& Jackson, 2005; but see McCauley, 2008). Their prey, i.e., amphibian larvae, have in turn been observed to avoid vegetation when insect predators were present (Rubbo et al., 2006; Smith \& Awan, 2009). The presence of chemical defenses in amphibian larvae may prove critical for sorting among habitats, as these defenses can vary in effectiveness against different types of predators; some species may perform better in habitats dominated by fish (Kats et al., 1988; Manteifel \& Reshetnikov, 2002; Üveges et al., 2019). Also, fish are gapelimited feeders (Sibbing, 1988), and tadpoles of some species may grow large enough to become invulnerable to fish predation, while insects with piercing mouthparts are less size-limited (Culler et al., 2014).

Responses of aquatic prey to the presence of multiple predators are generally inferred from smallscale experimental studies on specific prey species, whose relevance to natural complex and species-rich communities is often unclear (Wilbur \& Fauth, 1990; Anderson \& Semlitsch, 2016). Given the strong predatory pressure of fish and insects on amphibian larvae, the lack of field research on their natural distributions within ponds differing in predator assemblages is surprising. Although they do not allow for inference on individual species interactions, community-level field studies taking into account natural habitat complexity would not only verify the results from artificial experimental environments, but also provide vital information for wetland conservation management. Here, we examined spatial distributions of anuran tadpoles and their insect predators between open water as a simple habitat and emergent littoral vegetation as a complex habitat in the presence or absence of fish in semi-natural ponds. Both tadpoles and insects, especially those active when foraging, are at risk from fish (e.g., Healey, 1984; Henrikson, 1990; 
Kloskowski, 2011a; de Mendoza et al., 2012). Based on the differences in hunting modes and population size structure, we assumed that fish would pose a greater threat to predatory insects and their shared prey (tadpoles) in the less structured open-water habitat than in emergent vegetation (de Mendoza et al., 2012). On the other hand, tadpoles are under stronger predation pressure of sit-and-wait foraging insects in the emergent littoral vegetation and should be capable of better evading their attacks in open water (Formanowicz \& Bobka, 1989; Smith \& Awan, 2009; see also Relyea, 2001). Therefore, we predicted that compared to fishless ponds, in ponds containing fish the between-habitat distributions of insect predators and tadpoles vulnerable to fish would be skewed towards emergent littoral vegetation. Conversely, chemically defended Bufo bufo tadpoles, which are tolerant of fish but vulnerable to at least some predatory insects (Laurila, 1998; Manteifel \& Reshetnikov, 2002; Kloskowski, 2011b), were expected not to alter their behavior in response to fish and to stay mainly in open water (Laurila et al., 1997; Smith et al., 2009).

\section{Materials and methods}

Study system

The research was conducted in open ponds used for extensive culture of cyprinids, mainly common carp Cyprinus carpio, in south-eastern Poland (51 $17-33^{\prime}$ $\left.\mathrm{N}, 22^{\circ} 15-26^{\prime} \mathrm{E}\right)$. The ponds were normally filled and stocked in spring, and in autumn they were drained and the fish were harvested. The surface area of the ponds used in the study varied between 1 and 14 ha, except one pond of 18 ha. Water depth was fairly uniform across the pond, although it typically became shallower towards the shore. Mean depth ranged from 0.7 to $1.3 \mathrm{~m}$ over the sampling period. We used filled but unstocked ponds ("fishless ponds") and stocked ponds ("fish-containing ponds") to carry out a largescale natural experiment comparing the distributions of amphibian larvae and their insect predators between pond microhabitats. We sampled 35 ponds, in spring 2012 (14 ponds) and 2013 (21 ponds); 17 ponds were fishless and 18 ponds contained fish. Each pond was used only once in the study. While natural fishless and fish-containing ponds often differ in depth and hydroperiod (Wellborn et al., 1996), the advantage of our approach was that with the exception of some individual variation (size area, emergent vegetation cover) among ponds, the two types of ponds did not substantially differ in any morphological or environmental characteristics, i.e., fish effects were separated from environmental effects. All study ponds were situated in an agricultural landscape interspersed with small forest patches and were enclosed by a network of grassed levees and ditches. Given the homogeneity of the surrounding terrestrial matrix, we did not expect any sampling biases resulting from landscape-related variation in species abundance. The fish-containing ponds were stocked from March 23 to April 24. Screens of 2-3 mm mesh at water intakes prevented wild fish from entering the ponds via supplied water. Fish populations were fairly uniform among stocked ponds and consisted of 1- and 2-year-old cyprinids, mainly common carp (approx. 80-95\% of total stock biomass; stocked at individual mass of approx. 40-410 g). Additionally, small amounts (stock biomass of individual species typically $<10 \mathrm{~kg} / \mathrm{ha}$ ) of other carp species were stocked, i.e., grass carp Ctenopharyngodon idella, bighead carp Hypophthalmichthys nobilis, and crucian carp Carassius carassius. Total fish stocking densities in the ponds (about 100-280 kg/ha) were similar or lower than the natural densities attained by cyprinids in shallow eutrophic lakes (Scheffer, 2004). The stocked fish were large enough to present a predation risk to amphibian larvae and their insect predators in the ponds. Common carp is primarily benthivorous, not specialized in the capture of fast-moving prey due to the lack of grasping teeth (Sibbing, 1988). However, it is an opportunistic feeder, readily foraging on nonbenthic invertebrates and amphibian larvae and able to heavily suppress their populations via both consumptive and non-consumptive effect (Parkos et al., 2003; Rahman et al., 2010; Kloskowski, 2011a).

Habitat division into open water and complex littoral habitat

The ponds supported dense beds of emergent macrophytes along the shores, composed mainly of Phragmites australis, Typha angustifolia, T. latifolia and Schoenoplectus lacustris, usually several meters wide but occasionally extending up to $100 \mathrm{~m}$. Stem density in the overgrown areas varied between 72 and 182 
stems $\mathrm{m}^{-2}$ (based on counts of green and the previous year's dried-up stems in 20 ponds, using a $0.5 \mathrm{~m} \times 0.5 \mathrm{~m}$ frame at eight evenly distributed sites in the vegetated littoral zone per pond). The emergent littoral vegetation was difficult for larger fish to access (cf. Sychra et al., 2010), although its coverage was not uniform, with small poorly vegetated patches inside the macrophyte beds. The percentage of pond area covered by emergent macrophytes did not differ between ponds with and without fish (mean $28.8 \pm \mathrm{SE} \quad 3.8 \% \quad$ vs $31.3 \pm 3.5 \%, \quad t_{33}=0.51$, $P=0.610$ ). Owing to the overall shallowness of the ponds, under favorable conditions submerged macrophytes could occur across the entire bottom area. Nonetheless, during the study period there was an irregular yet distinct border in each pond between two roughly homogenous habitats: emergent vegetation belts along the shore (henceforth "littoral habitat") and open-water areas.

Sampling of predatory insects and amphibian larvae

Pond insects and tadpoles were captured using funnel activity traps between May 15 and May 19, 2012 and between May 17 and June 4, 2013 (when the season was delayed due to later ice-out), a period coinciding with the peak of larval amphibian occurrence in the ponds (Kloskowski, 2009). Trapping was used because traps effectively sample aquatic insects and tadpoles, including highly mobile species, in dense vegetation (cf. Becerra Jurado et al., 2008; Kloskowski, 2009), and also are not affected by the diel activity patterns of the sampled animals. The traps were made of 1-L plastic cylinders $220 \mathrm{~mm}$ in length with funnels about $100 \mathrm{~mm}$ at the base and $23 \mathrm{~mm}$ at the entrance (for details on trap construction see Nieoczym \& Kloskowski, 2015). The traps, placed on the bottom for $24 \mathrm{~h}$, were approximately evenly spaced across each pond, in pairs, 5-15 $\mathrm{m}$ in opposite directions from the outer edge of emergent macrophytes (towards the shore and the center of the pond). In each pond 10 traps were set in open water and 10 traps in the littoral habitat. Trapped tadpoles were determined to species (except for "water frogs" Pelophylax sp. and "brown frogs" Rana temporaria and $R$. arvalis, which were identified to genus) and released. They were roughly measured to be less than $40 \mathrm{~mm}$ total length. Predatory insects retrieved from the traps were preserved in $70 \%$ alcohol and later identified under a $10 \times$ microscope and measured. Trap catches are presented as numbers of individuals per 10 traps.

We classified Notonecta glauca and Ranatra linearis (Heteroptera), larval Anisoptera and Dytiscidae, and larger-sized ( $\geq 15 \mathrm{~mm}$ body length) adult dytiscids as predators ("insect predators") on amphibian larvae (Formanowicz \& Bobka, 1989; Henrikson, 1990; Tate \& Hershey, 2003; Klecka \& Boukal, 2012). Other potential invertebrate predators, predaceous Hirudinea, Zygoptera larvae, and Ilyocoris cimicoides (Heteroptera), were either captured only exceptionally or deemed too small to exert significant predatory pressure on tadpoles (Klecka \& Boukal, 2012).

Besides Pelophylax and Rana frogs, amphibian species trapped in the ponds were Bombina bombina, Pelobates fuscus, B. bufo, Bufotes viridis and Hyla orientalis. Omitted from the analyses were urodels (Triturus cristatus and Lissotriton vulgaris), which were rarely observed in the ponds. The anuran species occurring in the ponds are considered prone to fish predation (Kloskowski, 2011a; Buschendorf et al., 2016), except $B$. bufo tadpoles, which, due to the production of defensive toxins, are less susceptible to fish than to insect predators (Laurila, 1998; Manteifel \& Reshetnikov, 2002; Üveges et al., 2019) and whose response to fish predation risk diverges in that they typically display shoaling behavior (Watt et al., 1997; but see Anholt et al., 1996 and Laurila et al., 1998 for experiments in which $B$. bufo tadpoles have exhibited spatial avoidance of predators). Species palatable to fish may vary in antipredator behavior and susceptibility to individual fish species (Stauffer \& Semlitsch, 1993; Teplitsky et al., 2003; Buschendorf et al., 2016).

\section{Environmental measurements}

Environmental variables which could potentially affect habitat selection by insect predators and tadpoles (Kholin \& Nilsson 1998; Thurnheer \& Reyer, 2001; Sychra et al., 2010) were measured concurrently with insect/tadpole sampling. Submerged vegetation was collected using a Bernatowicz rake in 10 haphazardly selected open-water locations, roughly evenly spaced. Plants were dried to a stable biomass and weighed to $0.001 \mathrm{~g}$. We calculated dry plant biomass per bottom area unit $\left(\mathrm{g} \mathrm{m}^{-2}\right)$ as a proxy for habitat complexity. The dominant species were Chara sp., 
Stuckenia pectinata and Potamogeton lucens. Other environmental variables were measured in the midwater column, at about $30-50 \mathrm{~cm}$ above the bottom in both habitats, close to the trapping sites. Water temperature, oxygen concentration and conductivity were measured using a CX-401 ELMETRON meter. Total suspended solids (TSS) were estimated (PASTEL-UV SECOMAM spectrophotometer set to a 200-300 nm wavelength; means from three samples per habitat per site were calculated) because common carp causes an increase in suspended solids in the water through bioturbation and excretion of waste products (Matsuzaki et al., 2007), whereas macrophytes reduce suspended solid concentrations (reviewed in Scheffer, 2004). Samples were transported on ice to the laboratory and immediately analyzed.

\section{Statistical methods}

To assess the effects of fish and habitat complexity on insect predator and tadpole densities in the two pond habitats, we used generalized linear mixed effects models (GLMMs) with a log link and negative binomial distribution. Year was considered as a random factor. Since two data points (catches in open water and in littoral vegetation) were obtained from each pond, pond identity was entered as another random factor. Owing to low occurrence of Anisoptera larvae (recorded in only 6 ponds) and predatory Heteroptera (recorded in 5 ponds), we pooled them with dytiscids in the analyses. We ran separate GLMMs for individual anuran taxa; the two least common species, B. viridis and B. bombina, which occurred exclusively or mainly in fishless ponds (see "Results"), were omitted because their sample sizes and distributions did not allow for meaningful analyses. Submerged vegetation abundance in open water was highly related to fish presence (GLMM with identity link function and normal distribution of errors; see "Results"), and therefore it was not included as a fixed variable in the density distribution models. However, its effect on proportional habitat use by insect predators and the anuran taxa for which models on their relative densities were constructed was evaluated using GLMMs with a logit link and a binomially distributed error term. The number of individuals captured in open water was treated as a binomial response, while the total number of individuals recorded in the pond was the binomial denominator. Abiotic water parameter differences with regard to fish presence/absence and habitat type were also tested with GLMMs (identity link, normal errors). A Bonferroni correction for multiple testing was not applied (Moran, 2003). Significance levels were set at $P=0.05$. All analyses were conducted in GenStat v. 15 (VSN International Ltd.).

\section{Results}

Up to 8 species of insect predators were recorded in trap samples in each pond. The most common were dytiscids (adults or larvae), Agabus sp., present in 12 (34\%) ponds, Cybister lateralimarginalis and Rhantus latitans, each recorded from 9 (26\%) ponds). Sympetrum sp. had the highest frequency of occurrence in Anisoptera samples-4 (11\%) ponds. The most commonly occurring anurans were $B$. bufo, recorded in 25 (71\%) ponds, $P$. fuscus, observed in $23(66 \%)$ ponds, Pelophylax sp., in 18 (51\%) ponds, H. orientalis, in 16 (46\%) ponds, and Rana frogs, in 15 (43\%) ponds. The less commonly found species showed a strong negative response to fish presence; Bufotes viridis tadpoles occurred in only 9 ponds, all of them fishless, and Bombina bombina in 9 fishless ponds and 2 fishcontaining ponds.

The total relative densities of insect predators were not affected by fish presence/absence in the ponds, although there was a marginally significant tendency for insects to achieve higher densities in fish-containing ponds (Table 1, Fig. 1A). The relative densities of anuran taxa varied with respect to fish presence; $B$. bufo was clearly more abundant in ponds with fish, and the densities of $P$. fuscus and $H$. orientalis were significantly lower in fish-containing ponds than in fishless ponds, while Pelophylax and Rana frog densities did not differ between ponds with and without fish (Table 1). The main effects of habitat complexity indicated that insect predators and Rana tadpoles were more numerous overall in the littoral habitat, while P. fuscus and Pelophylax tadpoles preferred open-water habitat. A similar but only marginally significant tendency was found for B. bufo (Table 1). The relative densities of insect predators and all anuran taxa for which individual analyses were possible, including B. bufo, showed positive interactions between fish presence and the use of littoral habitat (Table 1, Fig. 1A-F). 
Of the physical and chemical water parameters, conductivity and TSS were higher in fish-containing ponds than in fishless ponds; also, conductivity was higher overall in the littoral habitat, while oxygen concentration was greater in open water (Tables 2,3). Submerged macrophyte biomass (log-transformed) showed a strong negative dependence upon fish presence (Wald $\chi^{2}=12.72$, df $=1, P<0.001$; mean biomass $3.3 \pm$ SE $0.8 \mathrm{~g} \mathrm{~m}^{-2}$ in fishless ponds vs $1.7 \pm 0.8 \mathrm{~g} \mathrm{~m}^{-2}$ in fish-containing ponds). Submerged macrophyte biomass did not affect the proportional habitat use by insect predators (Wald $\chi^{2}=0.07, \mathrm{df}=1, P=0.793$ ); however, the use of open water was highly positively related to submerged vegetation in all anuran species, including $B$. bufo (binomial GLMMs; Wald $\chi^{2} \geq 16.22$, df $=1$, all $P<0.001$ ), except $P$. fuscus, for which the relationship only approached significance (Wald $\chi^{2}=2.72$, df $=1, P=0.099$ ).

Table 1 Results of GLMM analyses (Poisson errors, log link function) of the effects of fish presence/absence and habitat type on relative densities of insect predators, fish-intolerant

\section{Discussion}

Between-habitat distributions

Both insect predators and tadpoles of all anuran taxa for which reliable analyses could be obtained occurred at relatively higher densities in the complex littoral habitat than in open water when fish were present in the ponds. The conventional explanation for reduced insect or tadpole densities in the presence of fish is predation. Actually, the within-pond distribution of insects and amphibians could to some extent be a passive process, in that they were disproportionately decimated by fish in open water (Crowder \& Cooper, 1982). However, given the broad evidence that many insects and larval amphibians are adapted to minimize risk of predation via microhabitat shifts (e.g., Pierce, 1988; Formanowicz \& Bobka, 1989), we argue that direct predation was unlikely to be the main mechanism (cf. Hanisch et al., 2012) and that spatial antipredatory behavior might contribute to the observed distribution patterns as well. Also, we cannot rule out

anuran tadpoles and fish-tolerant Bufo bufo tadpoles, with pond identity and year as random factors

\begin{tabular}{|c|c|c|c|c|c|}
\hline Relative densities & Predictor & Estimate (SED) & $F$-ratio & df & $P$ \\
\hline \multirow[t]{3}{*}{ Insect predators } & Fish status (absent, present) & $0.00,-2.18(0.73)$ & 3.03 & $1,34.7$ & 0.091 \\
\hline & Habitat (open water, littoral) & $0.00,0.03(0.31)$ & 5.64 & $1,34.0$ & 0.023 \\
\hline & Interaction fish presence $\times$ habitat & $0.00,1.96(0.69)$ & 5.20 & $1,34.0$ & 0.029 \\
\hline \multirow[t]{3}{*}{ Pelobates fuscus } & Fish status (absent, present) & $0.00,-2.93(0.81)$ & 7.18 & $1,32.6$ & 0.011 \\
\hline & Habitat (open water, littoral) & $0.00,-0.15(0.45)$ & 4.56 & $1,32.6$ & 0.040 \\
\hline & Interaction fish presence $\times$ habitat & $0.00,1.75(0.65)$ & 7.27 & $1,32.6$ & 0.011 \\
\hline \multirow[t]{3}{*}{ Bufo bufo } & Fish status (absent, present) & $0.00,1.20(0.64)$ & 26.99 & $1,33.3$ & $<0.001$ \\
\hline & Habitat (open water, littoral) & $0.00,-0.73(0.59)$ & 3.20 & $1,33.2$ & 0.083 \\
\hline & Interaction fish presence $\times$ habitat & $0.00,2.76(0.81)$ & 11.53 & $1,33.2$ & 0.002 \\
\hline \multirow[t]{3}{*}{ Hyla orientalis } & Fish status (absent, present) & $0.00,-4.43(0.86)$ & 30.51 & $1,33.1$ & $<0.001$ \\
\hline & Habitat (open water, littoral) & $0.00,-0.32(0.59)$ & 0.69 & $1,28.0$ & 0.414 \\
\hline & Interaction fish presence $\times$ habitat & $0.00,2.26(1.04)$ & 4.73 & $1,28.0$ & 0.038 \\
\hline \multirow[t]{3}{*}{ Rana sp. } & Fish status (absent, present) & $0.00,-1.62(0.45)$ & 2.61 & $1,31.9$ & 0.116 \\
\hline & Habitat (open water, littoral) & $0.00,0.18(0.35)$ & 20.58 & $1,33.0$ & $<0.001$ \\
\hline & Interaction fish presence $\times$ habitat & $0.00,1.92(0.50)$ & 14.57 & $1,33.0$ & $<0.001$ \\
\hline \multirow[t]{3}{*}{ Pelophylax sp. } & Fish status (absent, present) & $0.00,-3.66(0.96)$ & 2.14 & $1,31.7$ & 0.153 \\
\hline & Habitat (open water, littoral) & $0.00,-1.06(0.38)$ & 5.02 & $1,32.7$ & 0.032 \\
\hline & Interaction fish presence $\times$ habitat & $0.00,3.91(0.57)$ & 47.06 & $1,32.7$ & $<0.001$ \\
\hline
\end{tabular}

Standard errors of differences are given in parentheses 

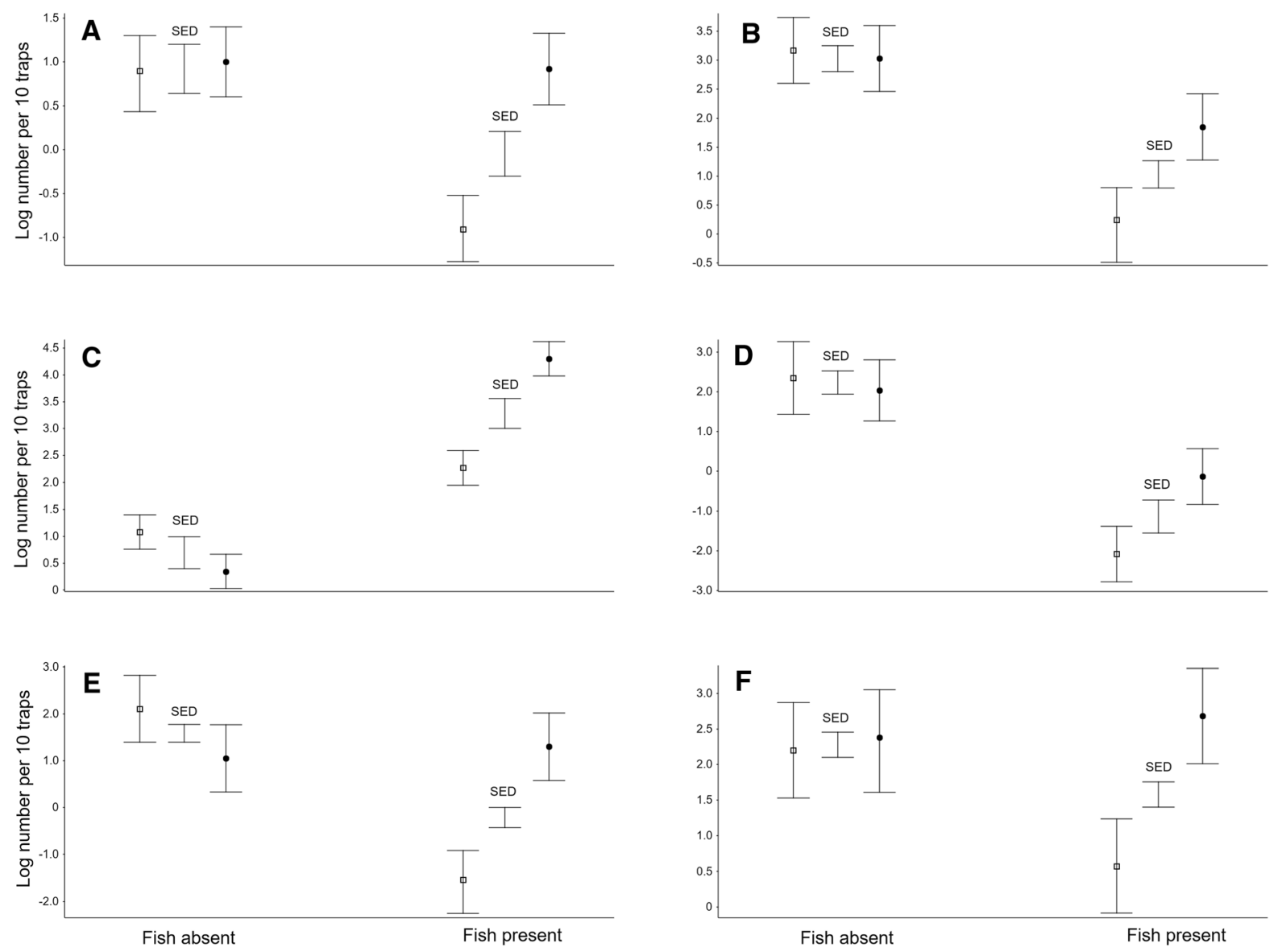

Fig. 1 GLMM predicted mean $( \pm \mathrm{SE})$ densities of insect predators (A), Pelobates fuscus (B), Bufo bufo (C), Hyla orientalis (D), Pelophylax sp. (E) and Rana sp. larvae (F) in open-water (open squares) and littoral (filled squares) habitat of

fishless and fish-containing ponds. The vertical lines between means represent standard errors of differences of means (SED) for comparisons between habitats within ponds

Table 2 Results of GLMM analyses (normal errors, identity link) of the effects of fish presence/absence and habitat type on physicochemical parameters of pond water

\begin{tabular}{|c|c|c|c|c|c|}
\hline Parameter & Predictor & Estimate (SED) & $F$-ratio & df & $P$ \\
\hline \multirow[t]{2}{*}{ Temperature $\left({ }^{\circ} \mathrm{C}\right)$} & Fish status (absent, present) & $0.00,-2.18(0.73)$ & 0.06 & 1,33 & 0.811 \\
\hline & Habitat (open water, littoral) & $0.00,0.03(0.31)$ & 0.97 & 1,34 & 0.331 \\
\hline \multirow[t]{2}{*}{ Oxygen concentration $\left(\mathrm{mg} \mathrm{l}^{-1}\right)$} & Fish status (absent, present) & $0.00,7.81(3.93)$ & 3.95 & 1,33 & 0.055 \\
\hline & Habitat (open water, littoral) & $0.00,-17.08(3.75)$ & 20.71 & 1,34 & $<0.001$ \\
\hline \multirow[t]{2}{*}{$\operatorname{TSS}\left(\mathrm{mg} \mathrm{l}^{-1}\right)$} & Fish status (absent, present) & $0.00,12.09(5.95)$ & 4.13 & 1,33 & 0.050 \\
\hline & Habitat (open water, littoral) & $0.00,-0.43(1.56)$ & 0.08 & 1,34 & 0.782 \\
\hline \multirow[t]{2}{*}{ Conductivity $\left(\mu \mathrm{S} \mathrm{cm}^{-1}\right)$} & Fish status (absent, present) & $0.00,58.18(23.24)$ & 6.27 & 1,33 & 0.017 \\
\hline & Habitat (open water, littoral) & $0.00,10.03(2.96)$ & 11.50 & 1,34 & 0.002 \\
\hline
\end{tabular}

Insignificant interactions were dropped from the models. Standard errors of differences are given in parentheses 
Table 3 GLMM means $( \pm$ SE) of abiotic parameters measured in open water and in the vegetated littoral habitat

\begin{tabular}{|c|c|c|c|c|c|}
\hline \multirow[t]{2}{*}{ Parameter } & \multicolumn{2}{|l|}{ Fish absent } & \multicolumn{3}{|l|}{ Fish present } \\
\hline & Open water & Vegetation & Open water & Vegetation & SED \\
\hline Temperature $\left({ }^{\circ} \mathrm{C}\right)$ & $28.9 \pm 0.5$ & $29.1 \pm 0.5$ & $29.2 \pm 0.5$ & $29.2 \pm 0.5$ & 0.5 \\
\hline Oxygen concentration $\left(\mathrm{mg} \mathrm{l}^{-1}\right)$ & $16.1 \pm 3.8$ & $5.8 \pm 3.7$ & $30.5 \pm 3.8$ & $7.0 \pm 3.7$ & 5.3 \\
\hline $\mathrm{TSS}\left(\mathrm{mg} \mathrm{l}^{-1}\right)$ & $26.6 \pm 4.3$ & $27.7 \pm 4.3$ & $39.7 \pm 4.4$ & $38.3 \pm 4.3$ & 4.8 \\
\hline Conductivity $\left(\mu \mathrm{S} \mathrm{cm}^{-1}\right)$ & $291.9 \pm 16.8$ & $302.6 \pm 16.6$ & $350.8 \pm 16.3$ & $360.1 \pm 16.5$ & 17.0 \\
\hline
\end{tabular}

SED average standard error of differences

that in the presence of fish some of the insect predators, such as large-bodied adult dytiscids, which are less vulnerable to fish due to individual size and a hard cuticle, did not seek shelter but were attracted to the structured vegetation by the abundance of prey behaviorally avoiding fish. The tendency of insects and amphibian larvae to stay in the littoral, usually more shallow zone could also be affected by microhabitat preferences based on abiotic characteristics, especially a preference for warmer water (Thurnheer \& Reyer, 2001; Tolonen et al., 2001; Hampton, 2004). The relationships between temperature selection and predation avoidance in tadpoles can be complicated by a number of factors, including tadpole developmental stage and species-specific forms of behavioral thermoregulation (Brattstrom, 1962; Wollmuth et al., 1987; Ultsch et al., 1999). However, abiotic conditions, including water temperature, were similar between pond microhabitats, presumably due to similar depth and the largely unrestricted water exchange between the littoral and the open-water zone, except that oxygen concentrations were higher in open water, likely due to the stronger mixing action of waves (cf. Přibáň \& Šmíd, 1978; Sychra et al., 2010). Conductivity was consistently higher in the littoral habitat than in open water, but the average difference was about $10 \mu \mathrm{S} \mathrm{cm}^{-1}$, which was unlikely to reflect any important contrasts in biotic or abiotic conditions. In shallow waterbodies such as these ponds, thorough mixing of the water occurs frequently, so horizontal gradients in chemical parameters or phytoplankton between habitats are unlikely to persist in the long term; however, the presence of submerged macrophytes may influence littoral-pelagic exchange (Barko \& James, 1998). Nevertheless, interactions between predation and modification of food resources by opportunist fish such as common carp are complex. Fish may increase pond resource levels through bottom-up effects (Horppila et al., 1998). When carp predation on tadpoles is precluded, environmental conditions for larval development in carp-dominated ponds can be more favorable than in the absence of fish, presumably mainly because bottom stirring by carp leads to resedimentation, facilitating tadpole access to re-suspended food particles (Kloskowski, 2011b). However, as indicated by the similar TSS levels, carp benthic feeding was unlikely to disproportionately increase tadpole resources in the littoral habitat relative to open water. Periphyton can be an important food source for amphibian larvae (Diaz-Paniagua, 1987; Brönmark et al., 1991; see also Dupuch et al., 2009), attracting them to vegetated littoral areas, but most larval anurans are primarily suspension-feeding omnivores (Seale \& Wassersug, 1979; Petranka \& Kennedy, 1999).

We expected B. bufo tadpoles to exhibit the opposite spatial response to taxa more prone to fish predation. However, despite the overall higher densities in fish-containing ponds than in fishless ponds, in the presence of fish $B$. bufo were relatively more numerous in the littoral zone, a modification of habitat use that was likely to enhance encounters with insect predators (Formanowicz, 1982; Tate \& Hershey, 2003; Smith \& Awan, 2009). Interpretation of this pattern is not straightforward, although the behavior is fairly consistent with the findings of Semlitsch \& Gavasso (1992) in experimental settings, where $B$. bufo responded to both Dytiscus larvae and vertebrate predators by shifting from open water to the edges of experimental containers (see also Porej \& Hetherington, 2005). The observed overall strong association 
with littoral vegetation could be accounted for by the feeding preferences of larval B. bufo (Diaz-Paniagua, 1987). Another possible explanation is that their distribution was shaped by fish predation (avoidance) after all, as B. bufo tadpoles are not fully protected from fish; their susceptibility may increase in the presence of tadpoles of palatable species, which dilute the protective effect of $B$. bufo chemical defenses (Kaczmarek et al., 2018).

As trap efficiency depends on the activity of the sampled animals, our results may be confounded by the differential activity levels of tadpoles in the uneven presence of different types of predators and in habitats with varying complexity (Becerra Jurado et al., 2008). Since activity increases prey exposure to vertebrate predators, tadpoles should show lower activity levels under predation risk from fish than from insects in fishless habitats (reviewed in Wellborn et al., 1996; Smith \& Awan, 2009). However, tadpoles of some anurans reduce their activity in the presence of insect predators as well (Laurila et al., 1998). Activity of insect predators typically decreases in the presence of fish, but the behavioral responses are speciesspecific and dependent on habitat structure (Pierce, 1988; Warfe \& Barmuta, 2004). Activity traps are likely to underestimate sit-and-wait foraging insects (Hampton \& Friedenberg, 2002; Michel \& Adams, 2009). Activity traps deployed for $24 \mathrm{~h}$ provide a cumulative picture of insect and tadpole distribution over this sampling period, unbiased by potential changes in activity and between-habitat shifts from day to night. On the other hand, potentially strong variation in spatial distribution between habitats over a short temporal scale (Hampton \& Friedenberg, 2002; Hampton, 2004), with important consequences for predator-prey dynamics, may remain concealed.

Pooling Pelophylax and Rana species to genera for analyses could mask inherent species differences in oviposition site preferences and habitat use by larvae (Berger, 1977; Kuzmin, 1999). Still, we assumed that, within their genera, the studied ranid species are genetically and ecologically similar enough (Van Buskirk, 2003) to display a common response to fish predation risk (Semlitsch \& Reyer, 1992; Stauffer \& Semlitsch, 1993). The consistent effects of the interactions of fish presence with habitat in models for all individual anuran taxa supported the general supposition that anuran species lacking chemical defenses shifted to complex habitat refugia (cf. Kats et al.,
1988). Similarly, given the wide range of foraging modes among closely related members of the insect community and their varied effectiveness as predators of tadpoles, treatment of all taxa as equal in the analyses is an oversimplification. However, the within-pond distribution patterns of insect predators appeared common to a wide array of taxa simply because in the presence of fish they were virtually absent from open water, so independently of foraging mode, they posed a threat to tadpoles only in vegetated littoral areas. Habitat selection by tadpoles may change with increased body size, as their mortality due to predation by size-limited predators, including fish such as common carp, is typically concentrated during the first weeks of larval life (Travis et al., 1985; Van Buskirk, 2001; Smith \& Awan, 2009; Kloskowski, 2011b). However, this could not introduce a significant interspecific bias, because the studied species which metamorphose at a large size, such as H. orientalis, P. fuscus or Pelophylax sp., are late breeders, achieving large body size later in summer (Kloskowski, 2009), and during the sampling period tadpoles of all species studied were relatively small.

In shallow ponds and lakes, the open-water zone is not an entirely simple habitat because submerged vegetation provides structure offering shelter and additional food resources, such as detritus (Carpenter \& Lodge, 1986), and thus it can affect invertebrate and tadpole distributions. The adverse impact of fish on submerged macrophytes (reviewed in Scheffer, 2004), which in our study presumably resulted from the feeding activity of common carp but also of the small numbers of co-occurring herbivorous grass carp (Matsuzaki et al., 2007; Kloskowski, 2011a; Francová et al., 2019), could additionally drive distribution shifts by predatory insects and tadpoles due to the loss of the principal structured microhabitat in the openwater area (Parkos et al., 2003). Littoral vegetation is resistant to fish because it is based on the well-rooted remains of the previous year's emergent macrophytes.

Potential combined effects of fish and insect predators

In the present study, we did not attempt to assess the individual or combined influence of fish and insect predators on tadpole mortality. The densities of some anuran taxa were clearly lower in ponds containing fish, suggesting that multiple predator types induced 
greater mortality than invertebrate predators alone in the fishless ponds. However, larval amphibian abundance in ponds is to a large extent determined by the non-random choice of oviposition site by adult females, aimed at minimizing the risk of predation to larvae; the presence of fish typically elicits a strong avoidance response (reviewed in Buxton \& Sperry, 2016). Anuran discrimination among oviposition sites appears to be confirmed by the virtual absence of $B$. bombina and $B$. viridis and the low overall densities of $P$. fuscus and $H$. orientalis in fish-containing ponds; however, we cannot rule out rapid tadpole elimination by actual predation.

If tadpole spatial distribution in ponds with fish resulted primarily from behavioral responses to simultaneous threats from fish and insect predators, the preference for vegetated littoral areas over openwater habitat indicates that fish posed a more imminent danger (cf. Krupa \& Sih, 1998; Relyea, 2003). This may appear trivial given the size and total biomass domination of fish in the ponds (see also Semlitsch \& Gavasso, 1992; Tate \& Hershey, 2003). However, Anisoptera larvae and dytiscids are no less dangerous predators, able to cause significant tadpole mortality (Wilbur \& Fauth, 1990; Gunzburger \& Travis, 2005; Anderson \& Semlitsch, 2016) and we are inclined to argue that, irrespective of causal factors behind within-pond tadpole distribution, habitat shift to littoral vegetation might increase larval amphibian vulnerability to sit-and-wait insect predators (Soluk \& Collins, 1988; see also Bofill \& Yee, 2019) as well as to widely foraging insects, which in the absence of fish would have fed in open water (Culler et al., 2014). Thus, fish presence can improve the conditions for insect predators that are themselves less vulnerable to fish than other mesopredators. The conflict between spatial responses to different predators does not necessarily result in overall risk enhancement, because prey may switch to other compensatory defenses (Krupa \& Sih, 1998). Tadpole use of a structurally complex habitat may serve as a generalized defense reducing the risk of predation by some insects as well (Babbitt \& Tanner, 1998; Babbitt \& Tarr, 2002; Kopp et al., 2006; see also Michel \& Adams, 2009).

Enhanced co-occurrence of insect predators in complex habitats may reduce their total abundance due to intensified IGP (reviewed in Culler et al., 2014; Ramos \& Van Buskirk, 2012). Similarly, fish can indirectly mitigate insect predation on tadpoles via
IGP as well as behavioral effects, e.g., interference or reduced insect activity in the presence of fish (Wissinger \& McGrady, 1993; Warfe \& Barmuta, 2004; but see González \& Tessier, 1997). However, as fish foraging is hampered by thick vegetation, fish IGP and interference with insect foraging can be insufficient to reduce total predation rates (by all predators) on tadpoles (Sih et al., 1998; Finke \& Denno, 2002; see also Swisher et al., 1998).

\section{Conclusions}

Natural experiments and observational studies of multiple predator effects are inferior to well-controlled, artificial-setting experiments in separating and explaining causal relationships; however, they deal with attributes of real systems, such as vast arrays of predators and prey or natural habitat complexity, and thus provide meaningful research and management insights. Here, in a large-scale, whole-system study, we found a strong influence of fish on the distribution of tadpoles and their insect predators between pond microhabitats. Insect predators and larval anurans displayed varying microhabitat preferences; overall, insects and Rana tadpoles were relatively more numerous in littoral habitat, while $P$. fuscus and Pelophylax tadpoles were relatively more abundant in open water (cf. Teplitsky et al., 2003). Also, differences in relative densities of individual anuran taxa between ponds with and without fish indicate their differential vulnerability to fish (Kats et al., 1988; Teplitsky et al., 2003). Nonetheless, insects and tadpoles showed a common distribution pattern, with increasing relative densities in littoral habitat in response to fish. While this is a speculative inference, as we did not estimate insect predation on anurans, we wish to draw attention to a potentially important indirect non-consumptive effect of fish: aggregation in complex vegetation in response to fish may put tadpoles at greater risk from insect predators, which are also driven to the same habitat by fish predation pressure. The use of emergent littoral vegetation may be particularly intensified in systems where openwater submerged macrophytes are adversely affected by fish. Our findings illustrate the importance of sampling various microhabitats during surveys of macroinvertebrates or larval amphibians in water bodies with heterogenous vegetation. Maintenance of vegetated habitat is often proposed as a key 
management action to support pond biodiversity (Porej \& Hetherington, 2005; Hartel et al., 2007; Kenison et al., 2016). Our data corroborate this recommendation, as predatory insects and anuran tadpoles shifted to littoral vegetation in the presence of fish. However, further community-level research is warranted to assess the potential emergent effects (sensu Sih et al., 1998) of fish and insect predation on amphibian larvae in relation to habitat complexity, because in fish-dominated ecosystems macrophyte refugia may be less effective in reducing total predation risk than expected.

Acknowledgements We would like to thank the pond managers for their cooperation with this study. We are grateful to P. Buczyński and W. Płaska for their help with the taxonomic identification of the insect samples. This study was conducted under permits DOP-oz. 6401.02.23.2012.JRO.2 and WPN.6401.42.2013.MO from the Regional Directorate for Environmental Protection in Lublin. The funding was provided by the University of Life Sciences in Lublin.

Open Access This article is licensed under a Creative Commons Attribution 4.0 International License, which permits use, sharing, adaptation, distribution and reproduction in any medium or format, as long as you give appropriate credit to the original author(s) and the source, provide a link to the Creative Commons licence, and indicate if changes were made. The images or other third party material in this article are included in the article's Creative Commons licence, unless indicated otherwise in a credit line to the material. If material is not included in the article's Creative Commons licence and your intended use is not permitted by statutory regulation or exceeds the permitted use, you will need to obtain permission directly from the copyright holder. To view a copy of this licence, visit http://creativecommons.org/licenses/by/4.0/.

\section{References}

Akre, B. G. \& D. M. Johnson, 1979. Switching and sigmoid functional response curves by damselfly naiads with alternative prey available. Journal of Animal Ecology 48: $703-720$.

Anderson, T. L. \& R. D. Semlitsch, 2016. Top predators and habitat complexity alter an intraguild predation module in pond communities. Journal of Animal Ecology 85: 548-558.

Anholt, B. R., D. K. Skelly \& E. E. Werner, 1996. Factors modifying antipredator behavior in larval toads. Herpetologica 52: 301-313.

Babbitt, K. J. \& G. W. Tanner, 1998. Effects of cover and predator size on survival and development of Rana utricularia tadpoles. Oecologia 114: 258-262.
Babbitt, K. \& T. Tarr, 2002. Effects of habitat complexity and predator identity on predation of Rana clamitans larvae. Amphibia-Reptilia 23: 13-20.

Barko, J. W. \& W. J. James, 1998. Effects of submerged aquatic macrophytes on nutrient dynamics, sedimentation, and resuspension. In Jeppesen, E., M. Søndergaard, M. Søndergaard \& K. Christoffersen (eds), The Structuring Role of Submerged Macrophytes in Lakes. Ecological Studies, Vol. 131. Springer, New York: 197-212.

Becerra Jurado, G., M. Masterson, R. Harrington \& M. KellyQuinn, 2008. Evaluation of sampling methods for macroinvertebrate biodiversity estimation in heavily vegetated ponds. Hydrobiologia 597: 97-107.

Berger, L., 1977. Systematics and hybridization in the Rana esculenta complex. In Taylor, D. H. \& S. I. Guttman (eds), The Reproductive Biology of Amphibians. Plenum Press, New York: 367-388.

Bofill, C. E. \& D. A. Yee, 2019. An army of one: predaceous diving beetle life history stages affect interactions with shared mosquito prey. Hydrobiologia 827: 201-209.

Brattstrom, B. H., 1962. Thermal control of aggregation behavior in tadpoles. Herpetologica 18: 38-46.

Brönmark, C., S. D. Rundle \& A. Erlandsson, 1991. Interactions between freshwater snails and tadpoles: competition and facilitation. Oecologia 87: 8-18.

Burks, R. L. \& D. M. Lodge, 2002. Cued in advances and opportunities in freshwater chemical ecology. Journal of Chemical Ecology 28: 1901-1917.

Buschendorf, J., A. Nöllert, W.-R. Grosse \& A. Geiger, 2016. Die Erdkröte-Ökologie und Verhalten. In Maletzky, A., A. Geiger, M. Kyek \& A. Nöllert (eds), Verbreitung, Biologie und Schutz der Erdkröte Bufo bufo (Linnaeus, 1758) mit besonderer Berücksichtigung des Amphibienschutzes an Straßen, Vol. 24. Deutsche Gesellschaft für Herpetologie und Terrarienkunde. Mertensiella, Mannheim: 67-70.

Buxton, V. L. \& J. H. Sperry, 2016. Reproductive decisions in anurans: a review of how predation and competition affects the deposition of eggs and tadpoles. BioScience 67: 26-38.

Carpenter, S. R. \& D. M. Lodge, 1986. Effects of submersed macrophytes on ecosystem processes. Aquatic Botany 26: 341-370.

Crowder, L. B. \& W. E. Cooper, 1982. Habitat structural complexity and the interaction between bluegills and their prey. Ecology 63: 1802-1813.

Culler, L. E., S. Ohba \& P. Crumrine, 2014. Predator-Prey Interactions of Dytiscids. In Yee, D. (ed.), Ecology, Systematics, and the Natural History of Predaceous Diving Beetles (Coleoptera: Dytiscidae). Springer, Dordrecht: 363-386.

de Mendoza, G., E. Rico \& J. Catalan, 2012. Predation by introduced fish constrains the thermal distribution of aquatic Coleoptera in mountain lakes. Freshwater Biology 57: 803-814.

Diaz-Paniagua, C., 1987. Tadpole distribution in relation to vegetal heterogeneity in temporary ponds. Herpetological Journal 1: 167-169.

Diehl, S. \& R. Kornijów, 1998. Influence of submerged macrophytes on trophic interactions among fish and macroinvertebrates. In Jeppesen, E., M. Søndergaard, M. Søndergaard \& K. Christoffersen (eds), The Structuring 
Role of Submerged Macrophytes in Lakes. Ecological Studies, Vol. 131. Springer, New York: 24-46.

Dupuch, A., L. M. Dill \& P. Magnan, 2009. Testing the effects of resource distribution and inherent habitat riskiness on simultaneous habitat selection by predators and prey. Animal Behaviour 78: 705-713.

Eklöv, P. \& T. VanKooten, 2001. Facilitation among piscivorous predators: effects of prey habitat use. Ecology 82: 2486-2494.

Fairchild, M. P. \& J. R. Holomuzki, 2005. Multiple predator effects on microdistributions, survival, and drift of stream hydropsychid caddisflies. Journal of the North American Benthological Society 24: 101-112.

Finke, D. L. \& R. F. Denno, 2002. Intraguild predation diminished in complex-structured vegetation: implications for prey suppression. Ecology 83: 643-652.

Formanowicz, D. R., 1982. Foraging tactics of larvae of Dytiscus verticalis (Coleoptera: Dytiscidae): the assessment of prey density. Journal of Animal Ecology 51: 757-767.

Formanowicz Jr., D. R. \& M. S. Bobka, 1989. Predation risk and microhabitat preference: an experimental study of the behavioral responses of prey and predator. American Midland Naturalist 121: 379-386.

Francová, K., K. Šumberová, G. A. Janauer \& Z. Adámek, 2019. Effects of fish farming on macrophytes in temperate carp ponds. Aquaculture International 27: 413-436.

González, M. J. \& A. J. Tessier, 1997. Habitat segregation and interactive effects of multiple predators on a prey assemblage. Freshwater Biology 38: 179-191.

Gunzburger, M. S. \& J. Travis, 2005. Effects of multiple predator species on green treefrog (Hyla cinerea) tadpoles. Canadian Journal of Zoology 83: 996-1002.

Hampton, S. E., 2004. Habitat overlap of enemies: temporal patterns and the role of spatial complexity. Oecologia 138: 475-484.

Hampton, S. E. \& N. A. Friedenberg, 2002. Nocturnal increases in the use of near-surface water by pond animals. Hydrobiologia 477: 171-179.

Hanisch, J. R., W. M. Tonn, C. A. Paszkowski \& G. J. Scrimgeour, 2012. Complex littoral habitat influences the response of native minnows to stocked trout: evidence from whole-lake comparisons and experimental predator enclosures. Canadian Journal of Fisheries and Aquatic Sciences 69: 273-281.

Hartel, T., S. Nemes, D. Cogălniceanu, K. Öllerer, O. Schweiger, C. I. Moga \& L. Demeter, 2007. The effect of fish and aquatic habitat complexity on amphibians. Hydrobiologia 583: 173-182.

Healey, M., 1984. Fish predation on aquatic insects. In Resh, V. H. \& D. M. Rosenberg (eds), The Ecology of Aquatic Insects. Praeger, New York: 255-288.

Heck, K. L. \& L. B. Crowder, 1991. Habitat structure and predator-prey interactions in vegetated aquatic systems. In Bell, S. S., E. D. McCoy \& H. R. Mushinsky (eds), Habitat Structure. Population and Community Biology Series, Vol. 8. Springer, Dordrecht: 281-299.

Henrikson, B. I., 1990. Predation on amphibian eggs and tadpoles by common predators in acidified lakes. Ecography 13: 201-206.
Holbrook, J. D. \& N. J. Dorn, 2016. Fish reduce anuran abundance and decrease herpetofaunal species richness in wetlands. Freshwater Biology 61: 100-109.

Horppila, J., H. Peltonen, T. Malinen, E. Luokkanen \& T. Kairesalo, 1998. Top-down or bottom-up effects by fish: issues of concern in biomanipulation of lakes. Restoration Ecology 6: 20-28.

Inoda, T., 2012. Predaceous diving beetle, Dytiscus sharpi sharpi (Coleoptera: Dytiscidae) larvae avoid cannibalism by recognizing prey. Zoological Science 29: 547-552.

Johansson, F., 1991. Foraging modes in an assemblage of odonate larvae-effects of prey and interference. Hydrobiologia 209: 79-87.

Kaczmarek, J. M., M. Kaczmarski, J. Mazurkiewicz \& J. Kloskowski, 2018. A matter of proportion? Associational effects in larval anuran communities under fish predation. Oecologia 187: 745-753.

Kats, L. B., J. W. Petranka \& A. Sih, 1988. Antipredator defenses and the persistence of amphibian larvae with fishes. Ecology 69: 1865-1870.

Kenison, E. K., A. R. Litt, D. S. Pilliod \& T. E. McMahon, 2016. Role of habitat complexity in predator-prey dynamics between an introduced fish and larval Long-toed Salamanders (Ambystoma macrodactylum). Canadian Journal of Zoology 94: 243-249.

Kholin, S. K. \& A. N. Nilsson, 1998. Regional enrichment of predacious water beetles in temporary ponds at opposite east-west ends of the Palearctic. Journal of Biogeography 25: 47-55.

Klecka, J. \& D. S. Boukal, 2012. Who eats whom in a pool? A comparative study of prey selectivity by predatory aquatic insects. PLoS ONE 7: e37741.

Kloskowski, J., 2009. Size-structured effects of common carp on reproduction of pond-breeding amphibians. Hydrobiologia 635: 205-213.

Kloskowski, J., 2011a. Consequences of the size structure of fish populations for their effects on a generalist avian predator. Oecologia 166: 517-530.

Kloskowski, J., 2011b. Impact of common carp Cyprinus carpio on aquatic communities: direct trophic effects versus habitat deterioration. Fundamental and Applied Limnology 178: 245-255.

Kopp, K., M. Wachlevski \& P. C. Eterovick, 2006. Environmental complexity reduces tadpole predation by water bugs. Canadian Journal of Zoology 84: 136-140.

Krivan, V., 1997. Dynamic ideal free distribution: effects of optimal patch choice on predator-prey dynamics. American Naturalist 149: 164-178.

Krupa, J. J. \& A. Sih, 1998. Fishing spiders, green sunfish, and a stream-dwelling water strider: male-female conflict and prey responses to single versus multiple predator environments. Oecologia 117: 258-265.

Kuzmin, S. L., 1999. The Amphibians of the Former Soviet Union. Pensoft Series Faunistica No. 12. Sofia and Moscow.

Laurila, A., 1998. Breeding habitat selection and larval performance of two anurans in freshwater rock pools. Ecography 21: 484-494.

Laurila, A., J. Kujasalo \& E. Ranta, 1997. Different antipredator behaviour in two anuran tadpoles: effects of predator diet. Behavioral Ecology and Sociobiology 40: 329-336. 
Laurila, A., J. Kujasalo \& E. Ranta, 1998. Predator-induced changes in life history in two anuran tadpoles: effects of predator diet. Oikos 83: 307-317.

Lima, S. L., 2002. Putting predators back into behavioral predator-prey interactions. Trends in Ecology \& Evolution 17: 70-75.

Manteifel, Y. B. \& A. N. Reshetnikov, 2002. Avoidance of noxious tadpole prey by fish and invertebrate predators: adaptivity of a chemical defence may depend on predator feeding habits. Archiv für Hydrobiologie 153: 657-668.

Matsuzaki, S. S., N. Usio, N. Takamura \& I. Washitani, 2007. Effects of common carp on nutrient dynamics and littoral community composition: roles of excretion and bioturbation. Fundamental and Applied Limnology 168: 27-38.

McCauley, S. J., 2008. Slow, fast and in between: habitat distribution and behaviour of larvae in nine species of libellulid dragonfly. Freshwater Biology 53: 253-263.

McCoy, M. W., A. C. Stier \& C. W. Osenberg, 2012. Emergent effects of multiple predators on prey survival: the importance of depletion and the functional response. Ecology Letters 15: 1449-1456.

Michel, M. J. \& M. M. Adams, 2009. Differential effects of structural complexity on predator foraging behavior. Behavioral Ecology 20: 313-317.

Moran, M. D., 2003. Arguments for rejecting the sequential Bonferroni in ecological studies. Oikos 100: 403-405.

Nieoczym, M. \& J. Kloskowski, 2015. Responses of epibenthic and nektonic macroinvertebrate communities to a gradient of fish size in ponds. Journal of Limnology 74: 50-62.

Palacios, M. M., M. E. Malerba \& M. I. McCormick, 2018. Multiple predator effects on juvenile prey survival. Oecologia 188: 417-427.

Parkos III, J. J., V. J. Santucci Jr. \& D. H. Wahl, 2003. Effects of adult common carp (Cyprinus carpio) on multiple trophic levels in a shallow mesocosms. Canadian Journal of Fisheries and Aquatic Sciences 60: 182-192.

Petranka, J. W. \& C. A. Kennedy, 1999. Pond tadpoles with generalized morphology: is it time to reconsider their functional roles in aquatic communities? Oecologia 120: 621-631.

Pierce, C. L., 1988. Predator avoidance, microhabitat shift, and risk-sensitive foraging in larval dragonflies. Oecologia 77: 81-90.

Porej, D. \& T. E. Hetherington, 2005. Designing wetlands for amphibians: the importance of predatory fish and shallow littoral zones in structuring of amphibian communities. Wetlands Ecology and Management 13: 445-455.

Přibáň, K. \& P. Šmíd, 1978. Climatic Conditions. In Dykyjová, D. \& J. Květ (eds), Pond Littoral Ecosystems. Structure and Functioning, Ecological Studies, Vol. 28. Springer, Berlin: 99-104.

Rahman, M. M., S. Kadowaki, S. R. Balcombe \& M. A. Wahab, 2010. Common carp (Cyprinus carpio L.) alters its feeding niche in response to changing food resources: direct observations in simulated ponds. Ecological Research 25: 303-309.

Ramos, O. \& J. Van Buskirk, 2012. Non-interactive multiple predator effects on tadpole survival. Oecologia 169: 535-539.
Relyea, R. A., 2001. Morphological and behavioral plasticity of larval anurans in response to different predators. Ecology 82: 523-540.

Relyea, R. A., 2003. How prey respond to combined predators: a review and an experimental test. Ecology 84: 1827-1839.

Rennie, M. D. \& L. J. Jackson, 2005. The influence of habitat complexity on littoral invertebrate distributions: patterns differ in shallow prairie lakes with and without fish. Canadian Journal of Fisheries and Aquatic Sciences 62: 2088-2099.

Richards, S. J. \& C. M. Bull, 1990. Non-visual detection of anuran tadpoles by odonate larvae. Journal of Herpetology 24: 311-313.

Rubbo, M. J., R. S. Mirza \& L. K. Belden, 2006. Evaluating a predator-prey interaction in the field: the interaction between beetle larvae (predator) and tadpoles (prey). Journal of Zoology 269: 1-5.

Savino, J. F. \& R. A. Stein, 1982. Predator-prey interaction between largemouth bass and bluegills as influenced by simulated, submersed vegetation. Transactions of the American Fisheries Society 111: 255-266.

Scheffer, M., 2004. Ecology of shallow lakes. Springer, New York.

Schilling, E. G., C. S. Loftin \& A. D. Huryn, 2009. Macroinvertebrates as indicators of fish absence in naturally fishless lakes. Freshwater Biology 54: 181-202.

Seale, D. B. \& R. J. Wassersug, 1979. Suspension feeding dynamics of anuran larvae related to their functional morphology. Oecologia 39: 259-272.

Semlitsch, R. D. \& S. Gavasso, 1992. Behavioural responses of Bufo bufo and Bufo calamita tadpoles to chemical cues of vertebrate and invertebrate predators. Ethology Ecology and Evolution 4: 165-173.

Semlitsch, R. D. \& H. U. Reyer, 1992. Modification of antipredator behaviour in tadpoles by environmental conditioning. Journal of Animal Ecology 61: 353-360.

Sibbing, F. A., 1988. Specializations and limitations in the utilization of food resources by the carp, Cyprinus carpio: a study of oral food processing. Environmental Biology of Fishes 22: 161-178.

Sih, A., G. Englund \& D. Wooster, 1998. Emergent impacts of multiple predators on prey. Trends in Ecology \& Evolution 13: $350-355$.

Smith, G. R. \& A. R. Awan, 2009. The roles of predator identity and group size in the antipredator responses of American toad (Bufo americanus) and bullfrog (Rana catesbeiana) tadpoles. Behaviour 146: 225-243.

Smith, G. R., A. Boyd, C. B. Dayer, M. E. Ogle \& A. J. Terlecky, 2009. Responses of grey treefrog and American toad tadpoles to the presence of cues from multiple predators. Herpetological Journal 19: 79-83.

Soluk, D. A. \& N. C. Collins, 1988. Synergistic interactions between fish and stoneflies: facilitation and interference among stream predators. Oikos 52: 94-100.

Stauffer, H. P. \& R. D. Semlitsch, 1993. Effects of visual, chemical and tactile cues of fish on the behavioural responses of tadpoles. Animal Behaviour 46: 355-364.

Swisher, B. J., D. A. Soluk \& D. H. Wahl, 1998. Non-additive predation in littoral habitats: influences of habitat complexity. Oikos 81: 30-37. 
Sychra, J., Z. Adámek \& K. Petřivalská, 2010. Distribution and diversity of littoral macroinvertebrates within extensive reed beds of a lowland pond. Annales de Limnologie-International Journal of Limnology 46: 281-289.

Tate, A. W. \& A. E. Hershey, 2003. Selective feeding by larval dytiscids (Coleoptera: Dytiscidae) and effects of fish predation on upper littoral zone macroinvertebrate communities of arctic lakes. Hydrobiologia 497: 13-23.

Teplitsky, C., S. Plénet \& P. Joly, 2003. Tadpoles' responses to risk of fish introduction. Oecologia 134: 270-277.

Thurnheer, S. \& H. U. Reyer, 2001. Spatial distribution and survival rate of waterfrog tadpoles in relation to biotic and abiotic factors: a field experiment. Amphibia-Reptilia 22: 21-32.

Tolonen, K. T., H. Hamalainen, I. J. Holopainen \& J. Karjalainen, 2001. Influences of habitat type and environmental variables on littoral macroinvertebrates communities in a large lake system. Archiv für Hydrobiologie 152: 39-67.

Travis, J., W. H. Keen \& J. Juilianna, 1985. The role of relative body size in a predator-prey relationship between dragonfly naiads and larval anurans. Oikos 45: 59-65.

Ultsch, G. R., S. A. Reese, M. Nie, J. D. Crim, W. H. Smith \& C. M. LeBerte, 1999. Influences of temperature and oxygen upon habitat selection by bullfrog tadpoles and three species of freshwater fishes in two Alabama strip mine ponds. Hydrobiologia 416: 149-162.

Üveges, B., M. Szederkényi, K. Mahr, Á. M. Móricz, D. Krüzselyi, V. Bókony, H. Hoi \& A. Hettyey, 2019. Chemical defense of toad tadpoles under risk by four predator species. Ecology and Evolution 9: 6287-6299.
Van Buskirk, J., 2001. Specific induced responses to different predator species in anuran larvae. Journal of Evolutionary Biology 14: 482-489.

Van Buskirk, J., 2003. Habitat partitioning in European and North American pond-breeding frogs and toads. Diversity and Distributions 9: 399-410.

Warfe, D. M. \& L. A. Barmuta, 2004. Habitat structural complexity mediates the foraging success of multiple predator species. Oecologia 141: 171-178.

Watt, P. J., S. F. Nottingham \& S. Young, 1997. Toad tadpole aggregation behaviour: evidence for a predator avoidance function. Animal Behaviour 54: 865-872.

Wellborn, G. A., D. K. Skelly \& E. E. Werner, 1996. Mechanisms creating community structure across a freshwater habitat gradient. Annual Review of Ecology and Systematics 27: 337-363.

Wilbur, H. M. \& J. E. Fauth, 1990. Experimental aquatic food webs: interactions between two predators and two prey. American Naturalist 135: 176-204.

Wissinger, S. \& J. McGrady, 1993. Intraguild predation and competition between larval dragonflies: direct and indirect effects on shared prey. Ecology 74: 207-218.

Wollmuth, L. P., L. I. Crawshaw, R. B. Forbes \& D. A. Grahn, 1987. Temperature selection during development in a montane anuran species, Rana cascadae. Physiological Zoology 60: 472-480.

Publisher's Note Springer Nature remains neutral with regard to jurisdictional claims in published maps and institutional affiliations. 